\title{
Epistaxis and Its Associated Factors Among Precollege Students in Southern Ethiopia
}

This article was published in the following Dove Press journal:

Journal of Blood Medicine

\author{
Gemechu Ameya (D) \\ Gelila Biresaw ${ }^{2}$ \\ Hayat Mohammed ${ }^{3}$ \\ Abebayehu Chebud ${ }^{4}$ \\ Melese Meskele ${ }^{5}$ \\ Mohammed Hussein ${ }^{6}$ \\ Muktar Endris ${ }^{7}$ \\ 'Department of Medical Laboratory \\ Sciences, College of Medicine and Health \\ Sciences, Kotebe Metropolitan \\ University, Addis Ababa, Ethiopia; \\ ${ }^{2}$ Department of Medical Laboratory \\ Sciences, College of Medicine and Health \\ Sciences, Arba Minch University, Arba \\ Minch, Ethiopia; ${ }^{3}$ Department of Medical \\ Laboratory Science, College of Medicine \\ and Health Science, Jimma University, \\ Jimma, Ethiopia; ${ }^{4}$ Melka Oda Primary \\ Hospital, West Guji, Melka Sodo, \\ Ethiopia; ${ }^{5}$ Worabe Comprehensive \\ Specialized Hospital, Worabe, Ethiopia; \\ ${ }^{6}$ Dessie Selam General Hospital, Dessie, \\ Ethiopia; ${ }^{7}$ Galikoma Health Center, Afar \\ Region, Galikoma, Ethiopia
}

Correspondence: Gemechu Ameya Department of Medical Laboratory Sciences, College of Medicine and Health Sciences, Kotebe Metropolitan University, P.O. Box: 3268, Addis Ababa, Ethiopia Tel +25 I-9l-783-768I

Email gemechuameya@gmail.com
Background: Epistaxis is one of the most common otorhinolaryngological emergencies affecting the majority of the population in their lifetime, with some of them requiring serious medical attention. This study aimed to assess the prevalence and associated factors of epistaxis among pre-college students in Wolaita Sodo, Ethiopia.

Methods: An institution-based cross-sectional study was conducted. Data were collected using a pre-tested interviewer administered questionnaire. The study participants were selected by systematic random sampling technique. A logistic regression analysis was employed to assess the presence and strength of association factors with epistaxis. An adjusted odds ratio with $95 \%$ confidence interval was used to determine the presence and strength of the association at 0.05 level of significance.

Results: Of 387 participants, $57.1 \%$ of them were male, and the mean age of all participant was 18.05 \pm 1.401 SD years. The overall epistaxis prevalence was 108 (27.9\%). Blood group $\mathrm{O}$, which accounted for about $43.4 \%$ was more prevalent. Blood group $\mathrm{O}$ ( $\mathrm{AOR}=3.96,95 \%$ $\mathrm{CI}=1.5-10.4$ ), participants who drink coffee daily ( $\mathrm{AOR}=2.75,95 \% \mathrm{CI}=1.0-7.4)$, and participants who took a bath frequently with both hot and cold-water (AOR $=4.55,95 \%$ $\mathrm{CI}=1.1-18.6)$ were significantly associated with epistaxis.

Conclusion: The type of blood group, interval of coffee drinking, and type of bathing were significantly associated with epistaxis. Working on the identified associated factor and increased awareness about epistaxis for the students with effective first aid training is mandatory.

Keywords: epistaxis, blood group, southern Ethiopia, pre-college students

\section{Introduction}

Epistaxis is a bleeding from the nose due to rupture of tiny, distended vessels in the mucous membrane of any area of the nose. ${ }^{1}$ There are a variety of causes associated with epistaxis, which are mainly categorized into an idiopathic and with symptoms of an underlying disease. ${ }^{2}$ The majority of epistaxis are anterior bleeds type, which are responsible for about $90-95 \%$ of the cases. ${ }^{3,4}$ In this type the most common site of bleeding is the anteroinferior aspect of the nasal septum in the anterior nasal cavity plexus vessels. ${ }^{4}$ In posterior bleeding it is difficult to find the bleeding point and it is highly intense in many cases. ${ }^{5}$ Posterior epistaxis is usually rare, it accounts for only $5-10 \%$ of cases. ${ }^{6}$

Although the majority of epistaxis cases are idiopathic, ${ }^{7,8}$ some causes have been identified so far in different studies. Trauma, ${ }^{7-9}$ hematological disorders, ${ }^{2-4,8-11}$ anatomic deformities, ${ }^{2,4,9}$ inflammatory reactions, ${ }^{8,9}$ organ failure, ${ }^{3,4,6,8,12}$ intranasal tumors, ${ }^{2,3}$ cardiovascular diseases,,${ }^{6,7,9}$ blood dyscrasias, ${ }^{4,13}$ low humidity, ${ }^{3,7,9,12}$ even 
vigorous nose blowing, ${ }^{1,9}$ and nose picking ${ }^{2,9,14}$ have been identified associated factors with epistaxis. In adults most cases are associated with medications such as non-steroidal anti-inflammatory drugs (NSAID) $)^{5,6,9,10,12,15}$ and anticoagulants such as heparin and warfarin. ${ }^{4,6,8,11}$

The most common inherited bleeding disorders associated with epistaxis are hemophilia A, hemophilia B, and von Willebrand diseases. ${ }^{9,11}$ Epistaxis is the most common symptom in approximately $60 \%$ of the patients with von Willebrand's disease. ${ }^{5}$ Superficial bleeding like epistaxis is usually associated with platelet defects or vascular disorders. ${ }^{11}$ Epistaxis is a common bleeding event that may be a symptom of coagulopathy. ${ }^{16,17}$ It is also more prevalent in a person with O-blood group. This blood type is associated with a lower expression of von Willebrand factor compared with non O-blood groups. ${ }^{18}$ This blood group also has a longer bleeding time compared to other blood groups, which confers the relative bleeding tendency. ${ }^{19}$ Therefore, this study helps to describe the extent of epistaxis and to predict the most likely factors associated with epistaxis.

There is limited study and data related to the associated factors of the case in the given area need to be identified. To the best of our knowledge, there is no study done in our setting to identify either the prevalence or associated factors on epistaxis. The true prevalence of epistaxis is hard to investigate because of the self-limiting characteristics of the disease. An episode of self-limiting epistaxis does not get reported. ${ }^{12}$ This makes the problem mostly ignored, and results in limited awareness in society on emergency first aid management of the disease. ${ }^{25}$ It is unclear how much the level of epistaxis is and which factors locally are associated to the case. Basically the distribution of epistaxis is common among young adults. ${ }^{5,7}$ If no efforts are put to determine the factors locally influencing epistaxis, it will be difficult to manage and treat epistaxis. The aim of this study was to assess the prevalence and associated factors of epistaxis among pre-college students in southern Ethiopia.

\section{Methods}

\section{Study Design and Settings}

An institutional-based cross-sectional study was conducted. The study was conducted in Wolaita Sodo town, the administrative center of the Wolaita Zone of the Southern Nations, Nationalities, and Peoples Region, Ethiopia. The lowest altitude of the town is 1,600 and the highest is 2,222 meters above sea level. And the mean annual temperature is $20^{\circ} \mathrm{C}$. In this city there are four pre-college (preparatory high schools); three of them private schools and the other is a public school. The estimated number of pre-college students was about 3,718.

\section{Study Population}

Students attending a preparatory high school in Wolaita Sodo town were used as a source of population. Selected students attending in a preparatory high school who fulfilled the inclusion criteria and were willing to participate in the study were the study population. Students who were on anti-thrombotic drugs and students who feel sick or had discomfort were excluded from the study.

\section{Sample Size Determination}

Sample size was calculated based on a single population proportion formula using the following assumptions. Due to the lack of a similar study in the study area, $P$-value $=0.5$ was used with 0.05 degree of freedom. After adding 10\% potential non-response, the sample size became 422 .

\section{Sampling Method}

The number and list of students in each school was obtained from the school director office of each preparatory high school. Based on the obtained information the study population was proportionally allocated to each preparatory high school under the study. For each high school, the allocated number of sample size of students was further allocated proportionally to each batch. The study subject was selected by systematic random sampling method. The first study subject was determined by lottery method.

\section{Data Collection Tool and Procedure}

Data was collected using a pre-tested and semi-structured interviewer administered questionnaire that is developed based on a previous study. 3,7,14,18-26 The questionnaire was first prepared in English and translated to local language (Amharic) for the data collection. The question was back-translated to English to check its consistency. The data collection tool contains questions related to sociodemographic characteristics of participants, epistaxis status, health-related factors, behavioral factors, and diet habits of the participants. The data were collected by five data collectors after receiving training.

\section{Specimen Collection and Processing}

The capillary blood from the finger was collected by cleaning the skin of the area around the fingertip with $70 \%$ isopropyl 
alcohol in a circular fashion beginning at the site and moving out ward. And the blood was collected by piercing the fingertip with a sterile lancet. Drops of blood were placed onto microscopic slides and a thin blood film wass made on the first slide for blood morphology examination and the blood grouping was done on the other slides using anti-A, anti-B, and anti-D reagents. The prepared thin blood film was fixed on the slide using methanol alcohol. Slides were stained using Giemsa stain in batch in the laboratory. Finally slides were examined under a microscope.

\section{Data Quality Control}

Data quality was ensured from data collection up to final laboratory results by following the prepared standard operating procedure. The questionnaire was prepared in English then it was translated to Amharic for data collection and backtranslated to English to check for consistency and completeness. Cross-checking of completeness of questionnaires was done during and after data collection. To ensure the validity and reliability of data collection, a pretest was done in Boditi secondary and preparatory high school in $5 \%$ of the sample size. Based on the finding of pre-test, necessary correction and modification were done.

\section{Data Analysis and Interpretation}

Data was first checked manually for completeness and then was coded and entered into Epi-Data version 3.1 statistical software and cleaned thoroughly before being transported to SPSS version 21 for further analysis. Descriptive statistics such as mean, frequencies, and percentages were used to describe and summarize the data. Binary logistic regression was used to determine the association between outcome variable and independent variables. Variables with a $P$-value $\leq 0.25$ in univariable binary logistic regression analysis were candidates for multivariable analysis and factors with $P<0.05$ in the final model were considered as statistically significant. The degree of association between dependent and independent variables were assessed using an adjusted odds ratio at $95 \%$ CI.

\section{Ethical Approval and Consent to Participate}

The study was conducted in accordance with the Declaration of Helsinki. Ethical clearance to conduct the study was obtained from the institutional ethical review of the college of medicine and health science, Arba Minch University. The institutional ethical review board was organized from seven committee members from different departments. Further permission was obtained from the zone education office and school directors before starting data collection. We guaranteed confidentiality by excluding names or any other personal identifiers from data-collection sheets and reports. The identifier for each eligible subject was replaced by a code, and no master code exists that allows the research data to be linked with the identifiers. Participants were informed about the aim of the study, the advantages of the study, and their rights even to stop in the middle of the procedure. Written and oral consent were taken from each participant before data collection. The study participants with critical results were attached to a clinical setting and all female participants with the Rhnegative blood group received information about what precautions they should take when they reach childbearing age. All students with the history of epistaxis got training on emergency management of nose bleeding.

\section{Results}

\section{Socio-Demographic Characteristics of Study Participants}

A total of 387 students participated in the study, with a response rate of $91.7 \%$. The mean age of participants'

Table I Socio-Demographic Characteristics of the Study Participants $(n=387)$

\begin{tabular}{|l|l|l|l|}
\hline \multicolumn{2}{|l|}{ Variables Category } & Frequency & $\begin{array}{l}\text { Percent } \\
\text { (\%) }\end{array}$ \\
\hline Age & $15-17$ & 133 & 34.4 \\
& $18-20$ & 233 & 60.2 \\
& $>20$ & 21 & 5.4 \\
\hline Sex & Male & 221 & 57.1 \\
& Female & 166 & 42.9 \\
\hline Level of & Grade IIth & 211 & 54.5 \\
\hline education & Grade I2th & 176 & 45.5 \\
\hline Fathers Job & Governmental employee & 187 & 13.4 \\
& Merchant & 94 & 24.3 \\
& Private worker & 45 & 11.6 \\
& Farmer & 9 & \\
\hline Participants' & Housewife & 165 & 42.6 \\
Mothers Job & Governmental employee & 121 & 31.3 \\
& Merchant & 76 & 19.6 \\
& Private worker & 23 & 5.9 \\
& Farmer & 2 & \\
\hline Family & $\leq 1,000$ birr & 12 & 3.1 \\
Income & I,00I-3,000 birr & 110 & 28.4 \\
& $>3,000$ & 265 & 68.5 \\
\hline
\end{tabular}




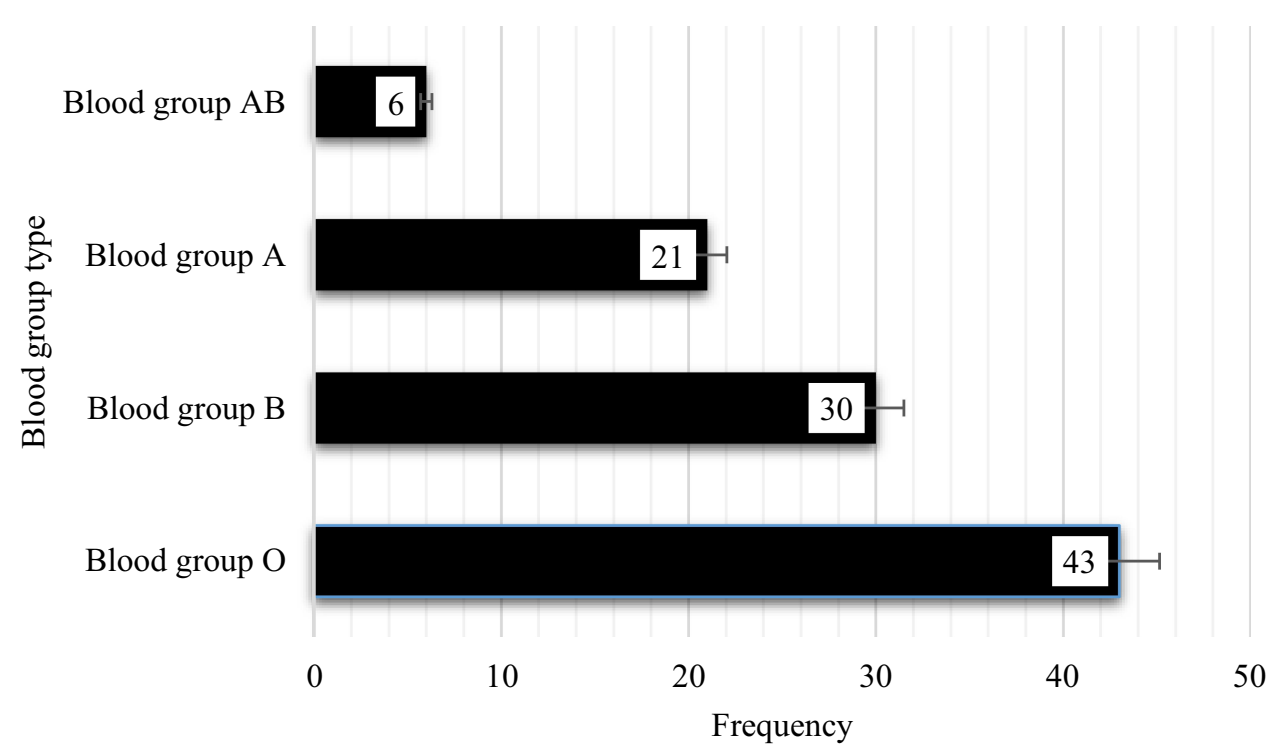

Figure I Blood group distribution of the study participants $(n=387)$.

was $18.05 \pm 1.401$ SD years. More than half $(221,57.1 \%)$ of the respondents were male. Regarding the job of the respondent's parent, 187 (48.3\%) fathers were governmental employees and 165 (42.6\%) mothers were housewifes. The majority of study participants $(375,96.9 \%)$ family income was above 1,000 birr per month (Table 1).

\section{Blood Group Distribution, Health, and Behavioral-Related Characteristics of the Study Participants}

The majority of study participants (43.4\%) have blood type $\mathrm{O}$, followed by blood type $\mathrm{B}$, while $\mathrm{AB}$ was the least prevalent type (Figure 1). The majority (345, $89.1 \%$ ) of participants had normocytic normochromic RBC appearance. Among 108 epistaxis cases, 37 (34.1\%) of them had a family history of epistaxis and nine (2.3\%) participants had heart disease. None of the study participants were aware of any coagulation disorder (Table 2).

A few (2.6\%) of study participants had a history of alcohol consumption and, from those participants, six of them took once a week. Almost all (99.5\%) participants had no history of cigarette smoking. Slightly higher than half of the study participant took a bath once a week, while nearly $40 \%$ of then took one 3-times per week. About one third of the participant used only cold water for bathing, and almost the same proportion use both warm and cold water (Table 2).

\section{Habit of Diet of the Study Participant}

More than half (61.8\%) of the participants had no habit of eating "datta" (spice mainly prepared from chili pepper, ginger, and garlic). Half of the participants that had a habit of eating "datta" ate only once a day with different foods. From all participants, 186 (48.1\%) of them had a history of drinking coffee. Of these, about one third of them drunk only

Table 2 Blood Group Distribution and Health-Related Characteristics of the Study Participants

\begin{tabular}{|c|c|c|c|}
\hline Variables & Category & Frequency & Percent (\%) \\
\hline RBC Morphology & $\begin{array}{l}\text { Normocytic } \\
\text { Normochromic } \\
\text { Normocytic } \\
\text { Hypochromic } \\
\text { Other }\end{array}$ & $\begin{array}{l}345 \\
27 \\
15\end{array}$ & $\begin{array}{l}89.1 \\
7.0 \\
3.9\end{array}$ \\
\hline Heart Disease & $\begin{array}{l}\text { Yes } \\
\text { No }\end{array}$ & $\begin{array}{l}9 \\
378\end{array}$ & $\begin{array}{l}2.3 \\
97.7\end{array}$ \\
\hline Alcohol & $\begin{array}{l}\text { Yes } \\
\text { No }\end{array}$ & $\begin{array}{l}10 \\
377\end{array}$ & $\begin{array}{l}2.6 \\
97.4\end{array}$ \\
\hline Cigarette Smoking & $\begin{array}{l}\text { Yes } \\
\text { No }\end{array}$ & $\begin{array}{l}2 \\
385\end{array}$ & 99.5 \\
\hline $\begin{array}{l}\text { Frequency of } \\
\text { Bathing }\end{array}$ & $\begin{array}{l}\text { Once a week } \\
\text { Two times a week } \\
\text { Three times a week } \\
\text { Every day }\end{array}$ & $\begin{array}{l}199 \\
30 \\
153 \\
5\end{array}$ & $\begin{array}{l}51.4 \\
7.8 \\
39.5\end{array}$ \\
\hline Type of bathing & $\begin{array}{l}\text { Cold shower only } \\
\text { Hot shower only } \\
\text { Both hot and cold shower }\end{array}$ & $\begin{array}{l}135 \\
128 \\
124\end{array}$ & $\begin{array}{l}34.9 \\
33.1 \\
32.0\end{array}$ \\
\hline
\end{tabular}


once per week. One hundred and thirty-four (34.6\%) of the participants reported the habit of drinking ginger tea and the majority of them drinking it 2-3 times in a week. Nearly half of the participants consumed vegetable as a usual food and 94 (39.8\%) of them ate vegetables $2-3$ times in a week. Slightly more than half of the participants had the habit of eating fruit and $81(40.3 \%)$ of them ate it only once in a week (Table 3 ).

\section{Prevalence of Epistaxis}

The overall epistaxis level in this study was 108 (27.9\%) (95\% CI $=23-32 \%)$. From all of the epistaxis participants, slightly more than half had their last episode within 3-6 months and $42.6 \%$ of them reported their number of episodes was between $2-5$ periods within a year. The same

Table 3 Habit of Diet of the Study Participants $(n=387)$

\begin{tabular}{|c|c|c|c|}
\hline Variables & Category & Frequency & $\begin{array}{l}\text { Percent } \\
\text { (\%) }\end{array}$ \\
\hline Datta eating & $\begin{array}{l}\text { Yes } \\
\text { No }\end{array}$ & $\begin{array}{l}148 \\
239\end{array}$ & $\begin{array}{l}38.2 \\
61.8\end{array}$ \\
\hline $\begin{array}{l}\text { Datta eating } \\
\text { frequency }\end{array}$ & $\begin{array}{l}\text { Daily } \\
\text { Once a week } \\
\text { Sometimes }\end{array}$ & $\begin{array}{l}105 \\
40 \\
3\end{array}$ & $\begin{array}{l}71.0 \\
27.0 \\
2.0\end{array}$ \\
\hline Coffee drinking & $\begin{array}{l}\text { Yes } \\
\text { No }\end{array}$ & $\begin{array}{l}186 \\
201\end{array}$ & $\begin{array}{l}48.1 \\
51.9\end{array}$ \\
\hline $\begin{array}{l}\text { Frequency of coffee } \\
\text { drinking }\end{array}$ & $\begin{array}{l}\text { Daily } \\
\text { Once a week } \\
2-3 \text { times a week } \\
\text { Sometimes }\end{array}$ & $\begin{array}{l}62 \\
67 \\
56 \\
1\end{array}$ & $\begin{array}{l}33.3 \\
36.0 \\
30.1 \\
0.6\end{array}$ \\
\hline Ginger tea & $\begin{array}{l}\text { Yes } \\
\text { No }\end{array}$ & $\begin{array}{l}134 \\
253\end{array}$ & $\begin{array}{l}34.6 \\
65.4\end{array}$ \\
\hline $\begin{array}{l}\text { Frequency of ginger } \\
\text { tea }\end{array}$ & $\begin{array}{l}\text { Daily } \\
\text { Once a week } \\
\text { 2-3 times a week } \\
\text { Sometimes }\end{array}$ & $\begin{array}{l}14 \\
12 \\
97 \\
11\end{array}$ & $\begin{array}{l}10.9 \\
9.0 \\
72.4 \\
8.2\end{array}$ \\
\hline $\begin{array}{l}\text { Types of food } \\
\text { consumed }\end{array}$ & $\begin{array}{l}\text { Vegetables } \\
\text { Meat } \\
\text { Cereals } \\
\text { Vegetables and } \\
\text { cereals } \\
\text { Cereals and meat }\end{array}$ & $\begin{array}{l}180 \\
51 \\
89 \\
52 \\
15\end{array}$ & $\begin{array}{l}46.5 \\
13.2 \\
23.0 \\
13.4 \\
3.9\end{array}$ \\
\hline Fruit Consumption & $\begin{array}{l}\text { Yes } \\
\text { No }\end{array}$ & $\begin{array}{l}201 \\
186\end{array}$ & $\begin{array}{l}51.9 \\
48.1\end{array}$ \\
\hline $\begin{array}{l}\text { Frequency of fruit } \\
\text { consumption }\end{array}$ & $\begin{array}{l}\text { Daily } \\
\text { Once a week } \\
\text { 2-3 times a week } \\
\text { Sometimes }\end{array}$ & $\begin{array}{l}50 \\
81 \\
68 \\
2\end{array}$ & $\begin{array}{l}24.9 \\
40.3 \\
33.8 \\
1.0\end{array}$ \\
\hline
\end{tabular}

Table 4 Epistaxis-Related Characteristics of the Study Participants $(n=108)$

\begin{tabular}{|c|c|c|c|}
\hline Variables & Category & Frequency & $\begin{array}{l}\text { Percent } \\
\text { (\%) }\end{array}$ \\
\hline $\begin{array}{l}\text { Last episode of } \\
\text { epistaxis }\end{array}$ & $\begin{array}{l}\text { Before I year } \\
6-12 \text { months } \\
3-6 \text { months } \\
<3 \text { months }\end{array}$ & $\begin{array}{l}4 \\
36 \\
57 \\
11\end{array}$ & \begin{tabular}{l|}
3.7 \\
33.3 \\
52.8 \\
10.2
\end{tabular} \\
\hline $\begin{array}{l}\text { Number of } \\
\text { episodes within } \\
\text { a year }\end{array}$ & $\begin{array}{l}\text { Once } \\
2-5 \\
6-7 \\
8-10 \\
>10\end{array}$ & $\begin{array}{l}4 \\
46 \\
39 \\
14 \\
5\end{array}$ & \begin{tabular}{l|}
3.7 \\
42.6 \\
36.1 \\
13.0 \\
4.6
\end{tabular} \\
\hline Nasal bleeding time & $\begin{array}{l}2-3 \mathrm{~min} \\
4-6 \mathrm{~min} \\
7-10 \mathrm{~min} \\
>10 \mathrm{~min}\end{array}$ & $\begin{array}{l}42 \\
19 \\
46 \\
1\end{array}$ & $\begin{array}{l}38.9 \\
17.6 \\
42.6 \\
0.9\end{array}$ \\
\hline $\begin{array}{l}\text { Cause of nasal } \\
\text { bleeding }\end{array}$ & $\begin{array}{l}\text { Trauma only } \\
\text { Nose picking } \\
\text { Dry weather only } \\
\text { Stress only } \\
\text { Hot bath } \\
\text { Both dry weather } \\
\text { and hot bath } \\
\text { Both dry weather } \\
\text { and stress } \\
\text { Both trauma and } \\
\text { stress }\end{array}$ & $\begin{array}{l}8 \\
14 \\
27 \\
32 \\
1 \\
3 \\
11 \\
12\end{array}$ & $\begin{array}{l}7.4 \\
13.0 \\
25.0 \\
29.6 \\
0.9 \\
2.8 \\
10.2 \\
11.1\end{array}$ \\
\hline
\end{tabular}

proportion of epistaxis participants reported their bleeding time was between $7-10$ minutes. About $30 \%$ of them responded that their cause of bleeding was stress only (Table 4).

\section{Factors Associated with Epistaxis}

Factors associated with epistaxis were assessed by binary logistic regression. In univariable analysis, sex, blood type, type and interval of bathing, frequency of "Datta" eating, frequency of coffee drinking, habit of drinking ginger tea, and fruit consumption had $P$-values less than 0.25 and the variables were selected for multivariable analysis. In multivariable analysis, the blood type of the students, coffee drinking, and type of bathing remained significantly and independently associated with epistaxis. Those participants with blood group $\mathrm{O}$ were about 4-times more likely to be affected by epistaxis than participants with non-O blood type ( $\mathrm{AOR}=3.96$, 95\% $\mathrm{CI}=1.5-10.4)$. Epistaxis was 2.6-times higher in participants who drink coffee daily than those 
Table 5 Factors Associated with Epistaxis Among the Participants $(n=387)$

\begin{tabular}{|c|c|c|c|c|c|}
\hline Variables & Epistaxis & None Epistaxis & COR $(95 \% \mathrm{Cl})$ & AOR $(95 \% \mathrm{Cl})$ & $P$-value \\
\hline \multicolumn{6}{|l|}{ Sex } \\
\hline Male & 77 & 144 & $2.33(1.4-3.8)$ & $2.09(0.7-5.8)$ & 0.158 \\
\hline Female & 31 & 135 & Ref. & Ref. & \\
\hline \multicolumn{6}{|l|}{ Blood group } \\
\hline Non-O-blood group & 43 & 176 & Ref & Ref. & \\
\hline O-blood group & 65 & 103 & $2.58(1.6-4.1)$ & $3.96(1.5-10.4)$ & $0.005^{*}$ \\
\hline \multicolumn{6}{|l|}{ Interval of bathing } \\
\hline Once per week & 55 & 144 & I.I3 (0.7-I.8) & $0.59(0.2-1.8)$ & 0.364 \\
\hline Twice per week & 13 & 17 & $2.26(1.0-5.1)$ & $0.79(0.2-3.8)$ & 0.766 \\
\hline More than twice per week & 40 & 118 & Ref. & Ref. & \\
\hline \multicolumn{6}{|l|}{ Type of water for Bathing } \\
\hline Cold water & 24 & 111 & Ref. & Ref. & \\
\hline Hot water & 40 & 88 & $2.10(1.2-3.7)$ & $1.98(0.6-6.4)$ & \\
\hline Both hot and cold water & 44 & 80 & $2.54(1.4-4.5)$ & $4.55(1.1-18.6)$ & $0.035^{*}$ \\
\hline \multicolumn{6}{|l|}{ Datta eating interval } \\
\hline Daily & 54 & 51 & $2.74(1.3-5.9)$ & $1.13(0.3-4.7)$ & 0.868 \\
\hline No daily & 12 & 31 & Ref. & Ref. & \\
\hline \multicolumn{6}{|l|}{ Coffee drinking habit } \\
\hline Yes & 71 & 115 & $2.74(1.7-4.4)$ & $2.6(0.9-7.3)$ & 0.064 \\
\hline No & 37 & 164 & Ref. & Ref. & \\
\hline \multicolumn{6}{|l|}{ Coffee drinking frequency } \\
\hline Daily & 32 & 30 & $2.33(1.2-4.3)$ & $2.75(1.0-7.4)$ & $0.044^{*}$ \\
\hline Not Daily & 39 & 85 & Ref. & Ref. & \\
\hline \multicolumn{6}{|l|}{ Drinking Ginger tea } \\
\hline Yes & 52 & 82 & $2.23(1.4-3.5)$ & $1.5(0.5-4.3)$ & 0.416 \\
\hline No & 56 & 197 & Ref. & Ref. & \\
\hline
\end{tabular}

Note: *Significant association.

participant who do not drink daily (AOR $=2.75,95 \%$ $\mathrm{CI}=1.0-7.4)$. Participants who took baths by both hot and cold-water were 4.6-times more likely to develop epistaxis than those who took cold showers (AOR $=4.55,95 \% \mathrm{CI}:=1$.1-18.6) (Table 5).

\section{Discussion}

The findings from this study showed that $27.9 \%(95 \%$ $\mathrm{CI}=23-32 \%$ ) of the study participants had epistaxis. This finding is in line with the study conducted in Dar es Salaam, Tanzania (23.4\%). ${ }^{7}$ In this study the level of epistaxis is higher compared to the findings of studies conducted in India (7.5\%) and Nigeria $(0.5 \%) .{ }^{3,28}$ This discrepancy could be because the study finding only represents the result from a single hospital and may be due to inadequate samples in the Nigerian study. Many studies ${ }^{3,12,15,27}$ conducted on epistaxis are hospital-based, but epistaxis cases are mostly self-limiting, ${ }^{12}$ and only a few seeks medical attention; ${ }^{6,7}$ so that the number of cases that will be presented in a health institution are rare.

Contrary with the above findings, the current study showed that the level of epistaxis is lower than the studies conducted in Saudi Arabia and India, where the level of epistaxis were $49 \%$ and $45 \%$, respectively. ${ }^{12,15}$ This might be attributable to the fact that the findings of a study conducted in Saudi Arabia were due to an incorporated large number of participants that were found in the kingdom of Saudi Arabia. In the case of India the discrepancy may be due to the different study design, which is retrospective, and the data collected for a prolonged time.

Out of the 108 participants with epistaxis, $60.2 \%$ of them were known to have blood type $\mathrm{O}$, which was also significantly associated with the case. This indicates the prevalence of epistaxis is higher in blood type $O$ than in the 
participants with other blood groups. Similar findings were observed in studies done in Nepal and India. ${ }^{18,27}$ The possible reason for the observed high association may be that the $\mathrm{O}$ blood group is known to be associated with a lower expression of von Willebrand factor which plays an important role in clotting compared with non-O blood groups. Bleeding time is recorded to be slightly longer in blood group $\mathrm{O} .{ }^{19}$

Type of bathing was also found to be significantly associated with epistaxis. In the current study participants who took a shower frequently by both hot and cold-water were more likely to developepistaxis. This may be due to the fluctuation in body temperature that affects the blood pressure of the participants. A study conducted in China showed the hourly temperature had a significant lag effect on blood pressure. ${ }^{28}$ Blood pressure changes with temperature based on different temperature and variation in blood pressure may induce epistaxis. Some other studies $^{3,7,17,26,29}$ show significant relations between epistaxis and hypertension. Unlike in our study, ingesting hot beverages and taking a hot bath were also highlighted as a contributing factor for epistaxis. ${ }^{30}$ The variation observed may be due to the study season and the difference in environmental temperature.

In the current study, the interval of coffee drinking habit was associated with epistaxis. Study participants who drink coffee daily were more likely to develop epistaxis than their counterparts. The findings of another study showed that caffeine in energy drinks has a nose bleeding effect. ${ }^{31,32}$ One of the most common causes of nose bleeds is dryness in the nasal passages, which can occur as a result of caffeine. This may be because caffeine dries out the body by pulling moisture from the mucous membranes of the nasal passages.

\section{Conclusion}

This study revealed that the level of epistaxis among preparatory students in Wolaita Sodo is relatively high. Blood type $\mathrm{O}$, drinking coffee daily and bathing with warm and cold water were significantly associated with epistaxis. Working on the identified associated factor is important to reduce the effect of the cases. It is better to increase awareness about epistaxis for the students and it is also better to give first aid training for the school community. Therefore, the health office and health extension workers need to better strengthen and maintain the local information dissemination network on epistaxis and its right time of commencement community-based information education and communication on epistaxis.

\section{Acknowledgment}

We would like to thank Arba Minch University colleges of medicine and health sciences department of Medical laboratory Science for giving us material support during laboratory analysis. We are very grateful to Wolaita Sodo preparatory high schools governors and Bodity health center staffs for cooperating during data collection.

\section{Disclosure}

The authors report no conflicts of interest for this work.

\section{References}

1. Sandra M, Brooks-Brunn J. Brunner \& Suddarth's Textbook of Medical-Surgical Nursing. 10th ed. Philadelphia: Lippincott Williams \& Wilkins; 2004.

2. Reyre A, Michel J, Santini L, et al. Epistaxis: the role of arterial embolization. Diagn Interv Imaging. 2015;96(7-8):757-774.

3. Moran N, Das D. Epistaxis - incidence, etiology, and management: A hospital-based study. Clin Rhinology. 2016;9(1):18-20.

4. Viehweg TL, Roberson JB, Hudson JW. Epistaxis: diagnosis and treatment. J Oral Maxillofacial Surg. 2006;64(3):511-518.

5. Marajo M, Secchi D, Lucia M, Indolfo P, Rabesquine MM. Epistaxis. Prevailing Factors Treat. 2009;13(4):381-385.

6. Villwock JA, Jones K. Recent trends in epistaxis management in the United States 2008-2010. JAMA Otolaryngol. 2013;139 (12):1279-1284.

7. Japhet MG, Phillipo LC. Etiological profile and treatment outcome of epistaxis at a tertiary care hospital in Northwestern Tanzania: a prospective review of 104 cases. BMC Ear Nose Throat Disord. 2011;11:8.

8. Pope LER, Hobbs CGL. Epistaxis: an update on current management. Postgrad Med J. 2005;81(955):309-314.

9. Fatakia A, Winters R, Amedee R. Epistaxis: a Common Problem. Ochsner J. 2010;10(3):176-178.

10. Fathy H, Ismail R, Mahmoud N, Abdel WM. Recurrent epistaxis in children: when should we suspect coagulopathy? Egypt J Otolaryngology. 2014;30(2):106-111. doi:10.4103/1012-5574.1 33207

11. Salih AA, Majeed EA. Relation between Epistaxis and hematological - disorders. Arch Med Health Sci. 2012;18(3):143-149.

12. Alhaddad MS, Almulhim K, Mubarak IAS, Alotaibi N, Hussain MAS, Alyahya KA. Prevalence of epistaxis in saudi population. Int J Sci Study. 2017;5(9):96-99.

13. Soto-Galindo GA, Treviño González JL. Epistaxis diagnosis and treatment update: a review. Ann Otolaryngol Rhinol. 2017;4(4):1176.

14. Michael R, Meera C, Derek L, et al. Epistaxis as a Common Presenting Symptom of Glanzmann's Thrombasthenia, a Rare Qualitative Platelet Disorder: Illustrative Case Examples. Hindawi Publishing Corporation; 2017.

15. Sharma K, Kumar S, Islam T, Krishnatreya M. A retrospective study on etiology and management of epistaxis in elderly patients. Arch Med Health Sci. 2015;3(2):234-238. doi:10.4103/2321-4848.171911

16. Kemal O, Müderris T, Sevil E, Kutlar G. Relation of mean platelet volume and red blood cell distribution width with epistaxis. Laryngoscope. 2015;125(4):788-790. doi:10.1002/lary.24990

17. Karabulut AE, Çevik Y, Emektar E, Çorbacioğlu Ş, Dağar S, Yardim O. Analysis of mean platelet volume and red blood cell distribution width in recurrent epistaxis. Turkish $\mathrm{J} \mathrm{Em} \mathrm{Med}$. 2018;18(2):67-70. doi:10.1016/j.tjem.2018.02.001

18. Adhikari P, Pramanik T. Relation of blood group with epistaxis. Int Arch Otorhinolaryngology. 2008;12(4):513-516. 
19. Adhikari P, Pramanik T, Pokharel R, Khanal S. Relationship between blood group and epistaxis among Nepalese. Nepal Med College J. 2008;10(4):264-265.

20. Simmen DB, Jones NS, Cummings CW, Flint PW, Harker LA. Epistaxis. Otolaryngology Head Neck Surg. 2005;5:682-693.

21. Ando Y, Iimura J, Arai S, et al. Risk factors for recurrent epistaxis: importance of initial treatment. Auris Nasus Larynx. 2014;41 (1):41-45.

22. Varshney S, Saxena RK. Epistaxis: a retrospective clinical study. Indian J Otolaryngology Head Neck Surg. 2005;57:2.

23. Pallin DJ, Chng YM, McKay MP. Epidemiology of epistaxis in U.S. emergency departments, 1992 to 2001. Ann Emerg Med. 2005;46:77-81.

24. Sauter TC, Hegazy K, Hautz WE. Epistaxis in anticoagulated patients: fewer hospital admissions and shorter hospital stays on rivaroxaban compared to phenprocoumon. In: Clinical Otolaryngology. 2017:1-6.

25. Alshehri F, Alluwaim F, Alyahya K. Teachers' awareness regarding emergency management of epistaxis inside the school; alahssa, Saudi Arabia. Open J Prev Med. 2018;8:44-55.

26. Acar B, Yavuz B, Yıldız E, Ozkan S, Ayturk M, Sen O. A possible cause of epistaxis: increased masked hypertension prevalence in patients with epistaxis. Braz J Otorhinolaryngol. 2017;83(1):45-49.
27. Mirdha M, Jena SK. Distribution of blood group and its relation to bleeding time and clotting time. Int J Med Sci Public Health. 2016;5 (12):2566-2569.

28. Xu D, Zhang Y, Wang B, et al. Acute effects of temperature exposure on blood pressure: an hourly level panel study. Environ Int. 2019;124:493-500.

29. Kodiya AM, Labaran AS, Musa E, Mohammed GM, Ahmad E. Epistaxis in Kaduna, Nigeria: A review of 101 cases. Afr Health Sci. 2012;12(4):479-482.

30. Ahmed HS, Abdullah MA, Ahmed AA, Manal IBM, Marzouki HZ. Epistaxis: what do people know and what do they do? Global j Ortholrygology. 2018;13:2.

31. Nowak D, Jasionowski A. Analysis of the consumption of caffeinated energy drinks among Polish adolescents Int. J Environ Res Public Health. 2015;12:7910-7921.

32. Kapner AD Ephedra and energy drinks on college campuses. the higher education center for alcohol and other drug abuse and violence prevention. 2004. Available from: http://files.eric.ed.gov/fulltext/ ED537639.pdf. Accessed on 5 March 2020.
Journal of Blood Medicine

\section{Publish your work in this journal}

The Journal of Blood Medicine is an international, peer-reviewed, open access, online journal publishing laboratory, experimental and clinical aspects of all aspect pertaining to blood based medicine including but not limited to: Transfusion Medicine; Blood collection, Donor issues, Transmittable diseases, and Blood banking logistics; Immunohematology; Artificial and alternative blood based
Dovepress

therapeutics; Hematology; Biotechnology/nanotechnology of blood related medicine; Legal aspects of blood medicine; Historical perspectives. The manuscript management system is completely online and includes a very quick and fair peer-review system. Visit http://www.dovepress.com/testimonials.php to read real quotes from published authors. 